\title{
"Dos rigores do cativeiro ao cárcere de uma penitenciária": libertos em Sergipe no pós-abolição
}

\author{
Petrônio Domingues ${ }^{*}$ \\ ${ }^{1}$ Universidade Federal de Sergipe, São Cristóvão/SE - Brasil \\ Edvaldo Alves de Souza ${ }^{2 * *}$ \\ ${ }^{2}$ Universidade Federal de Sergipe, São Cristóvão/SE - Brasil
}

\section{RESUMO}

$\mathrm{O}$ artigo aborda o mundo dos libertos em Sergipe no século XIX, especialmente analisa a atitude de "ex-escravos" prisioneiros que entraram com ação na justiça para tentar conquistar a liberdade depois da Abolição, que pôs fim à escravidão no Brasil, em 1888. A ideia central é mostrar como os "ex-escravos" - esses sujeitos subestimados por décadas pela historiografia - buscaram capitalizar os novos direitos que a legislação lhes facultava. Ao agenciarem as barras dos tribunais, eles se apropriavam de prerrogativas republicanas, inserindo seus interesses em uma emergente linguagem da cidadania.

Palavras-chave: liberto; ex-escravo; pós-abolição; justiça; direitos.

\section{“Of captivity rigors to captivity in jail”: post-abolition freedom in Sergipe}

\section{ABSTRACT}

The present article addresses the world of freedmen of Sergipe in the nineteenth century. It focuses on the attitude of "ex-slaves" prisoners who filed a lawsuit in order to conquer freedom after the Abolition, which ended slavery in Brazil in 1888. The main idea is to show how "ex-slaves" - who have been underestimated by historiography for decades — sought to capitalize on the new rights which were given to them by law. These individuals took hold

DOI: http://dx.doi.org/10.1590/2237-101X02004209.

Artigo recebido em 29 de maio de 2018 e aceito para publicação em 13 de fevereiro de 2019.

* Professor da Universidade Federal de Sergipe / Departamento de História / Programa de Pós-Graduação em História, campus São Cristóvão/SE - Brasil. E-mail: pjdomingues@yahoo.com.br. ORCID: https://orcid. org/0000-0002-0116-5064.

** Mestre em História pela Universidade Federal de Sergipe / Departamento de História / Programa de Pós-Graduação em História, campus São Cristóvão/SE - Brasil. E-mail: edvaldo.asn@gmail.com. ORCID: http://orcid.org/0000-0002-4070-7006. 
of Republican prerogatives and asserted their interests in an emerging citizenship language by conquering the bars of courts.

Keywords: freed; ex-slave; post-abolition; justice; rights.

\section{"De los rigores del cautiverio a la cárcel de una penitenciaria": libertos en Sergipe en la post-abolición}

\section{RESUMEN}

El artículo aborda el mundo de los libertos en Sergipe en el siglo XIX, especialmente analiza la actitud de "exesclavos" prisioneros que entraron con acción en la justicia para intentar conquistar la libertad después de la Abolición, que puso fin a la esclavitd en Brasil en 1888. La idea central es mostrar como los "exesclavos" - esos sujetos subestimados por décadas por la historiografía - buscaron capitalizar los nuevos derechos que la legislación les facultaba. $\mathrm{Al}$ negociar en las barras de los tribunales, ellos se apropiaban de prerrogativas republicanas, colocando sus intereses en un emergente lenguaje de ciudadanía.

Palabras clave: liberto; exesclavo; post-abolición; justicia; derechos.

Em meio à consulta da imensa quantidade de caixas e pacotilhas que compóe o acervo histórico do Arquivo Geral do Judiciário do Estado de Sergipe (AGJES), eis que surge uma folha amarelada e frágil, bastante castigada pela ação do tempo e das traças. Nela, abaixo da identificação do Tribunal da Relação do Estado de Sergipe, órgão emissor do documento, lê-se com extrema dificuldade: "Odorico, ex-escravo". O texto logo é interrompido pela deterioração das partes seguintes, o que impossibilitou nossa tentativa de compilá-lo na íntegra. De inteligível, restou uma frase posta ao final da folha, na qual se lê: "é merecedor da graça impetrada para lhe ser perdoada o resto da pena que lhe foi aplicada". Documento datado de 1895 , trata-se de um parecer sobre um pedido de graça. ${ }^{1}$

À luz da lei estadual de no 12 , de 27 de julho de 1892, que regulamentava o perdão e a comutação de pena, as graças eram concedidas pelo presidente do Estado ou pela Assembleia Legislativa, sendo que, ao primeiro, cabia arbitrar sobre as penas impostas aos réus que cometessem crimes comuns, enquanto que a segunda se encarregava dos funcionários públicos em crimes funcionais. ${ }^{2}$

\footnotetext{
${ }^{1}$ Arquivo Geral do Judiciário do Estado de Sergipe (AGJES). AJU/C. TJ. Queixa Crime. Cx. 01/1461 05/07/1895.

${ }^{2}$ CARDOSO, Brício; ROMÉRO, Benilde. Compilaçâo das leis, decretos e regulamentos do Estado de Sergipe. II volume, 1892-1893. Aracaju: Tipografia d' O Estado de Sergipe, 1900, p. 61-64.
} 
O pedido de perdão ou comutação da pena poderia ser impetrado por qualquer cidadáo. A princípio, era endereçado ao juiz de direito, que produzia um relatório no qual narrava o crime e apresentava informaçóes acerca da vida pregressa do autor do pedido, daí, entâo, era remetido ao presidente do Estado que, por sua vez, encaminhava para o Tribunal da Relação para saber se o solicitante era ou não merecedor da graça imputada. As idas e vindas do pedido poderiam finalizar nas mãos do presidente quando fosse de sua competência para dar a palavra final, ou remetida à Assembleia caso o solicitante fosse um funcionário público. ${ }^{3}$

Explicados os procedimentos para a obtenção do perdão ou da comutação da pena, convém retomar o caso de Odorico, visto tratar-se de um "ex-escravo" presidiário que se valeu do instrumental jurídico disponível para tentar conquistar a soltura sete anos depois da promulgação da Lei Áurea, que aboliu a escravidão no Brasil. Além disso, não nos pareceu fortuita a classificação de "ex-escravo" que lhe foi impingida. O estigma do ex-escravo é significativo de um período de discussão a respeito dos limites da liberdade dos novos cidadãos. Tomando por base as informaçóes dispersas da peça judicial envolvendo Odorico, não há como saber, a princípio, se o seu pedido de graça significou o passaporte para a liberdade. De todo modo, sua investida junto ao Tribunal da Relaçáo do Estado de Sergipe abre caminho para refletirmos sobre a trajetória de ex-escravos sentenciados cuja luta pela liberdade não pereceu com a lei "redentora", de 13 de maio de 1888.

Olívia Maria da Cunha e Flávio Gomes salientam a necessidade de apreender a libertação dos escravos para além da assinatura da Lei Áurea, com o seu eixo político tradicional. O processo de inserção social, observado no cotidiano dos egressos do cativeiro, foi bastante complexo e multifacetado, por isso a necessidade de repensar a Abolição como marco de total ruptura em torno da liberdade e seus significados. "A transformação do escravo em livre esteve longe de trilhar um caminho linear e irreversível", ${ }_{4}^{4}$ assinalam Cunha e Gomes. Em muitos casos, a liberdade não significou o avesso da escravidão, assim como a sujeição, subordinação e desumanização, que conferiam inteligibilidade à experiência do cativeiro, e acabaram sendo reconfiguradas depois do 13 de maio de 1888 .

Se, outrora, trajetórias como a de Odorico foram negligenciadas pela historiografia, hodierno, isso parece estar mudando. Tem-se operado uma consolidação do campo temático batizado de "pós-abolição", com um crescente número de pesquisadores envidando esforços para descortinar novas tramas, vozes e personagens que viveram a experiência da escravidão, saber dos seus destinos, entender a lógica e multiplicidade de decisóes e escolhas que tiveram de fazer num momento crucial da nossa história. Esse foi um mo-

\footnotetext{
${ }^{3}$ Em alguns casos, o procurador geral do Estado era nomeado para substituir o presidente do Estado no deferimento ou não do pedido de perdão ou comutação da pena.

${ }^{4}$ CUNHA, Maria Gomes da; GOMES, Flavio dos Santos (orgs.). Quase-cidadão: histórias e antropologias do pós-emancipação no Brasil. Rio de Janeiro: Editora FGV, 2007, p. 9.

${ }^{5}$ MATTOS, Hebe; RIOS, Ana Maria. O pós-abolição como problema histórico: balanço e perspectivas. Topoi, v. 5, n. 8, 2004, p. 170-198.
} 
mento de transformaçóes políticas e institucionais relacionadas ao fim da Monarquia e à instalação da República, transformaçôes que, em muitos aspectos, redefiniram as possibilidades de inserção social e conquista de direitos das populaçôes emergentes do cativeiro do campo e das cidades.

Neste artigo, nosso intuito é investigar aspectos da história de Odorico e de outros libertos sentenciados cujos embates em prol da liberdade não feneceram com a extinção do regime de cativeiro no Brasil. Nosso principal argumento é de que, para esses sujeitos, a justiça se constituiu um fórum estratégico onde puderam lutar por prerrogativas entendidas como direitos e questionar sua própria condição. Como adverte E. P. Thompson, o poder judiciário não é neutro, refletindo as contradiçôes de classe e relaçôes assimétricas de poder, renda e prestígio, mas ele também náo é previamente determinado. Nesse sentido, os processos judiciais são resultados das disputas e conflitos que configuram o campo jurídico. Isso implica considerar que, mesmo reconhecendo que os grupos subordinados de uma sociedade têm menos probabilidades de sair vencedores nas ações judiciais confrontando o Estado ou os grupos dominadores, eles nem sempre saem derrotados. Thompson acredita que a arena jurídica realmente pode atuar como equipamento de mediação entre as classes em conflitos, contribuindo para demarcar, definir e redefinir as próprias relaçóes sociais. ${ }^{6}$ Apoiando-se, portanto, nos pressupostos do historiador inglês, postulamos que os libertos se valeram da justiça como um importante lócus de questionamento e de ressignificação dos conceitos de escravidáo e liberdade. Ao agenciarem as barras dos tribunais, eles demandavam por direitos, inserindo seus interesses em uma emergente linguagem da cidadania.

\section{A escravidão acabou, mas a liberdade não chegou}

O AGJES dispóe de um importante acervo histórico, ainda pouco explorado no que tange à temática do pós-abolição. ${ }^{7}$ A propósito, a documentação do AGJSE, que aparece neste artigo, foi garimpada pela equipe do projeto $O$ negro no pós-abolição em Sergipe (18881900): trabalho, familia e lazer, coordenado por Petrônio Domingues. O projeto consistiu no trabalho de localização, consulta, seleção e digitalização de mais de uma centena de açôes judiciais, especialmente processos criminais cujos personagens (vítimas, testemunhas ou réus) eram libertos. Recebeu a chancela do Ministério da Cultura (MinC), da Universidade Federal de Pernambuco (UFPE) e da Fundação Joaquim Nabuco (FUNDAJ), de

\footnotetext{
${ }^{6}$ THOMPSON, E. P. Senhores e caçadores: a origem da lei negra. Rio de Janeiro: Paz e Terra, 1987.

${ }^{7}$ Até o momento as únicas pesquisas sobre esse campo temático, realizadas a partir das fontes do AGJES, são: DOMINGUES, Petrônio; ALVES, Edvaldo e NUNES, Cláudia. O “cativeiro se acabou”: experiências de libertos em Sergipe no pós-abolição. História, histórias. Brasília, v. 4, n. 8, 2016, p. 93-112; SOUZA NETO, Edvaldo Alves de. Saindo das senzalas, mas não da história: libertos em Sergipe no pós-abolição (1888-1900). São Cristóvão: Editora UFS, 2017.
} 
acordo com o Edital PROEXT/PROPESQ-UFPE 2013: Preservação e acesso aos bens do patrimônio afro-brasileiro. ${ }^{8}$

Cabe retornar agora à história do protagonista da trama até aqui. Contando com uma dose de sorte entre um achado e outro no acervo do AGJES, localizamos os passos de Odorico uma segunda vez. Agora, por meio do processo de petição de graça, uma verdadeira porta de acesso a mais informaçôes sobre o caso. Odorico era escravo do Doutor José de Aguiar Botto de Barros, proprietário do engenho Pombinho, localizado no município de Maruim, estado de Sergipe. Nesse engenho, Odorico acabou se envolvendo em uma contenda com Gil, o feitor da propriedade, na madruga de 3 de fevereiro de 1887. Pelos documentos arrolados na petição, não é possível saber quais os motivos que serviram de estopim para o conflito; certo é que Odorico, munido de uma faca, proferiu golpes e feriu Gil na região do abdômen, provocando seu falecimento horas mais tarde. Odorico fugiu do local do crime e se entregou na delegacia de Aracaju. Foi a julgamento e acabou sentenciado a pena de galés perpétuas, sendo enclausurado na cadeia dessa cidade. ${ }^{9}$

A "Casa de Prisão" de Aracaju foi inaugurada em 1869, no centro da capital sergipana, nas proximidades da Praça 24 de Outubro..$^{10}$ Possuía, em 1883, dois pavimentos, com 50 celas ( 24 no piso superior e 26 no inferior), e 264 presos separados por sexo. ${ }^{11}$ Era considerada a melhor e maior cadeia do estado. Mesmo assim, o prédio era "contra todos os preceitos de higiene", situação vivenciada de perto por todos que por lá passavam. Ao longo do tempo, a "Casa de Prisão" foi alvo de críticas e preocupaçôes de autoridades públicas, no tocante ao ambiente de promiscuidade, às doenças e à ociosidade dos presos. Esses enfrentavam péssimas condições de encarceramento, que iam desde a lotação das celas, os maus tratos (p. ex., o recebimento de vestimentas e alimentação insuficientes) até a ausência de critérios de separação conforme os delitos cometidos, o que fazia com que a cadeia pública fosse "ao mesmo tempo, casa de correção, hospício de alienados e penitenciária". ${ }^{12}$ No século XIX, esse quadro de precariedade de acomodação se repetia em outras prisóes do estado de Sergipe e alhures, o que levou Marcos Bretas a designar tais estabelecimentos como "lugares de morte". Em estudo sobre a Casa de Correção do Rio de Janeiro, esse historiador coligiu estatísticas impressionantes: 245 dos 1.099 internos que entraram entre junho de 1850 e dezembro de 1869 morreram na prisão. Se excluirmos os sentenciados a penas de menos de

\footnotetext{
${ }^{8}$ Além da figura do coordenador, a equipe do projeto contou com a participação de três assistentes de pesquisa: Edvaldo Alves de Souza Neto (na época mestrando em História - UFS), Cláudia Nunes (doutoranda em Arqueologia - UFS) e Selma Santos (graduada em Biblioteconomia e Documentação - UFBA). Trata-se do primeiro e, até agora, único projeto em Sergipe do gênero, o que tem facilitado o acesso de fontes inéditas do judiciário sergipano para vários pesquisadores.

${ }_{9}^{9}$ AGJES. AJU/C. TJ. Penal. Petição de graça. Cx. 01/1445 - 01/07/1895.

${ }^{10}$ SEBRÃO SOBRINHO. Laudas da história de Aracaju. Aracaju: Regina, 1955, p. 356.

${ }^{11}$ CARDOSO, Amâncio. O quinto dos infernos: presídios em Sergipe no século XIX. In: MENEZES, Joelina (org.). Segurança pública: gestão, formação e valores. São Cristóvão: Editora UFS, 2012, p. 189-190.

${ }^{12}$ LISBOA, Silva L. C. Chorografia do Estado de Sergipe. Aracaju: Imprensa Oficial, 1897, p. 79.
} 
dois anos, temos 236 mortes entre 656 internos (36\%). Para os condenados a mais de dez anos, as taxas de mortalidade excederam $50 \%$, e, entre os 32 internos sentenciados a mais de vinte anos, 27 morreram, dois foram transferidos, e dois foram perdoados. "O único sobrevivente", afirma Bretas, "havia entrado na prisão um ano antes; podemos apenas imaginar por quanto tempo ele ainda sobreviveria". ${ }^{13}$

No que tange à "Casa de Prisáo" de Aracaju, as condiçôes de precariedade de encarceramento na instituição parecem não ter passado por significativas mudanças nos anos posteriores à Abolição. Em março de 1890, a transferência de presos chocou um articulista da Gazeta de Sergipe. As "cenas mais tristes que já nos foi dado presenciar", referia-se o articulista ao "embarque de 52 indivíduos acusados de latrocínio". Fitados por vários curiosos presentes na Praça 24 de Outubro, aqueles infelizes saíam da cadeia pública "magros, cambaleantes de fome" e "nus", sob os "prantos e gritos" "de amigos e parentes" que não sabiam qual seria o destino de cada um deles. $\mathrm{O}$ articulista anônimo asseverava que aqueles sujeitos eram ainda indiciados (qual seja, presos cautelares) e não sentenciados, por isso acabou criticando a justiça sergipana: "há de doer muito na consciência dos seus juízes ao certificarem-se um dia de que entre [aqueles sujeitos] viviam homens sãos". ${ }^{14}$

Odorico, embora tenha praticado o crime de homicídio contra o feitor da propriedade onde era escravo, não teve seu nome incluso na lista dos embarcados. Continuava na masmorra de Aracaju. Atento às possibilidades abertas pela nova legislação estadual que regulamentava o perdáo e a comutação de pena, ele, por intermédio de seu advogado, impetrou um pedido de graça, que, em 1 de julho de 1895, foi remetido ao Tribunal da Relação, o que nos permitiu conhecer mais um pouco sobre o caso. Além de ter sido preso durante o regime escravista, sabemos que Odorico recebeu a "boa nova" da Abolição em uma das selas da cadeia pública de Aracaju. Na aurora republicana, continuava sua batalha judicial para conseguir a tão sonhada liberdade, sendo essa tentativa, de 1895 , a segunda delas. ${ }^{15}$

Manoel da Fonseca, autor da petição em favor de Odorico, acusou de parcial o tribunal de Maruim, local onde Odorico cometeu o crime e foi julgado. Essa parcialidade, segundo o advogado, devia-se à influência que os antigos senhores ainda exerciam nas decisóes judiciais, levando os tribunais a se inclinarem a interesses distintos daqueles presentes na letra da lei. Talvez isso explique o motivo pelo qual Odorico, para o cumprimento da pena, optou por se apresentar à delegacia de Aracaju e não à de Maruim. Considerando que seu cliente fora vítima de uma injustiça, o advogado alardeava: "até hoje ainda não pôde passar um só dia de tranquilidade e gozo, porque de um desgraçado escravo dos rigores de um horrível cativeiro passou a ser condenado do cárcere de uma penitenciária” ${ }^{16}$ A partir daí, o advogado

\footnotetext{
${ }^{13}$ BRETAS, Marcos Luiz. O que os olhos não veem: histórias das prisões no Rio de Janeiro. In: MAIA, Clarissa Nunes et al (orgs.). História das prisóes no Brasil. v. 2. Rio de Janeiro: Rocco, 2009, p. 189.

14 "Embarque". Gazeta de Sergipe. Aracaju, 22/03/1890, p. 2.

${ }^{15}$ AGJES. AJU/C. TJ. Penal. Petição de graça. Cx. 01/1445 - 01/07/1895.

${ }^{16}$ AGJES. AJU/C. TJ. Penal. Petição de graça. Cx. 01/1445 - 01/07/1895.
} 
evocava o estatuto republicano de cidadania. Para construir uma sociedade civilizada e cada vez mais justa, os princípios de liberdade, igualdade (perante a lei) e fraternidade deviam nortear as decisóes judiciais, o que garantiria a Odorico a prerrogativa de cidadáo, já que "liberto" e não mais escravo.

Ao ser provocado, Manoel Pinto Ramalho, o procurador geral do estado de Sergipe, produziu uma súplica. A tese da inexistência de parcialidade no julgamento de Odorico foi mantida, tendo em vista que o tribunal que proferiu a sentença era formado por "indivíduos íntimos amigos, compadres e parentes" do ex-senhor. Manoel de Carvalho finalizava sua súplica repetindo um trecho do que o advogado de Odorico havia escrito:

até hoje, não passa um só dia de tranquilidade e gozo, porque de um infeliz escravo dos rigores de um bárbaro cativeiro passou a ser condenado dentro de uma penitenciária perdendo a luz da sociedade. ${ }^{17}$

Entendendo que a penalidade imposta pelo júri havia sido excessiva, o procurador geral do Estado emitiu um parecer favorável ao pedido de graça, finalmente acatado pelo presidente do Estado em 9 de junho de 1895, data em que Odorico pôde reconhecer "a luz da sociedade" e sentir o gosto da liberdade.

Os embates travados por Odorico nas malhas do poder judiciário, em favor da sua liberdade, foram marcados por expectativas e percepçôes normativas. Com a abolição da escravidão e a mudança de regime político, a legislação foi reelaborada em muitos lugares das Américas, com a redefinição dos direitos de cidadania e liberdade. ${ }^{18}$ Apesar das dificuldades de comunicação com o mundo exterior à prisão, os libertos sentenciados tinham noções não só de direitos como também do estabelecimento formal de critérios republicanos de cidadania, fatores que talvez tenha feito a diferença na maneira como eles percebiam suas vidas, agiam e acionavam a justiça no período posterior à abolição. Suas lutas foram informadas por aspiraçôes pessoais à liberdade. E também pelo repúdio a qualquer experiência que remontasse à escravidão. Estar encarcerado, para aqueles libertos, era uma dessas experiências associadas ao cativeiro.

\section{Outras histórias}

Para nossa surpresa, na medida em que compulsávamos a documentação do acervo do AGJES, descobrimos que a trajetória de Odorico não era a única. Outros nomes saltaram aos

\footnotetext{
${ }^{17}$ AGJES. AJU/C. TJ. Penal. Petição de graça. Cx. 01/1445 - 01/07/1895.

${ }^{18}$ GRINBERG, Keila; PEABODY, Sue. Escravidão e liberdade nas Américas. Rio de Janeiro: Ed. FGV, 2013, p. 127.
} 
nossos olhos e nos mostraram que acionar o judiciário, como via de acesso à liberdade, foi a estratégia seguida por outros sujeitos em condiçôes semelhantes ao do nosso protagonista.

Por esse mesmo caminho, trilhou Rufino, também identificado como "ex-escravo", só que agora do finado Antônio José da Silva. Rufino foi acusado de, no dia 3 de outubro de 1879, em um lugar próximo à Vila de Rosário do Catete, na região sergipana da Cotinguiba, agredir duramente com golpes de faca a região torácica de André Avelino de Azevedo, que veio a óbito momentos depois. Isso ocorreu à noite, no momento em que André voltava do canavial onde amiúde fazia visitas para expulsar os ladróes que estavam atacando as roças da região. Rufino disse que era natural da Vila do Rosário, residente no sítio Lagoa do Cachorro e trabalhador de enxada nas roças da sua senhora. Assim como no caso de Odorico, ele acabou recebendo a pena de galés perpétuas no dia 30 de junho de 1883, aplicada pelo júri do município de Japaratuba. ${ }^{19}$

Argumentando que não havia "robustas provas" para incriminar Rufino e que a pena proferida tinha sido muito rigorosa, seu advogado entrou na justiça com um pedido de graça no ano de 1895; àquela altura, o sentenciado já estava há mais de dezesseis anos vivendo em regime de privação de liberdade. Antes de se pronunciar sobre a matéria, Gustavo Sampaio, o procurador geral do estado de Sergipe, consultou José Joaquim de Britto, o "administrador da Casa de Prisão", para saber sobre a conduta de Rufino. Então o administrador traçou um pequeno histórico do sentenciado, registrando sua extensa lista de infraçóes. Qualificado de "rebelde e incorrigível”, Rufino carregaria plenos sinais de má índole, razão pela qual seria repudiado pelos outros prisioneiros. ${ }^{20}$

O histórico comportamental no cárcere foi fator decisivo para o desfecho do caso. Não deu outra. O procurador geral exarou parecer negativo ao pedido de graça, entendendo ser a sentença de Rufino uma puniçáo justa, tanto pelo que observou nos autos, como pelas informaçôes do "administrador da Casa de Prisão". Em tese, Rufino não se reabilitara, mesmo após dezesseis anos vivendo na masmorra. Pelo menos do ponto de vista das autoridades públicas, não era tido como alguém passível de viver em uma sociedade livre, seja pelos costumes reprováveis como escravo ou pela indisciplina apresentada na Casa de Prisão de Aracaju.

As avaliaçóes das autoridades judiciárias e penitenciárias refletiam a insegurança, os temores e os imaginários raciais relacionados aos impactos do fim do cativeiro. Para os que se manifestaram contrários à abolição, o argumento corrente era de que teria como consequência o crescimento da marginalidade, da desordem e da criminalidade. Pensava-se que a escravidão era o freio de uma população naturalmente propensa ao crime, vício, indisciplina e devassidão. ${ }^{21} \mathrm{O}$ racismo das elites, especialmente dos ex-senhores e autoridades públicas, recrudescia e se projetava nos seus medos e fantasmas. Nos primeiros anos de

\footnotetext{
${ }^{19}$ AGJES. AJU/C. TJ. Escravos. Cx.01/1463 - 24/12/1895.

${ }^{20} \mathrm{Idem}$. grifo nosso.

${ }^{21}$ AZEVEDO, Célia Maria Marinho de. Onda negra, medo branco: o negro no imaginário das elites - século XIX. 3. ed. São Paulo: Annablume, 2004.
} 
abolição, circulavam - em Sergipe e em outras localidades do Brasil - narrativas, imagens e representaçôes a respeito dos libertos que os definiam como seres indolentes, vadios, boçais, suspeitos, perigosos e despreparados para a vida em liberdade. ${ }^{22}$ Portanto, para Rufino conseguir o perdão ou a comutação da pena, precisava não só se converter num sujeito "melhor", reabilitado, como também extirpar a sua suposta má índole, que ainda amedrontava o administrador da cadeia pública de Aracaju. ${ }^{23}$

Outra história intrigante foi a de Malaquias, "ex-escravo" do Barão de Itabaiana. Acusado de, no dia 21 de novembro de 1886, ter assassinado cruelmente sua companheira, de nome Shymphoroza (à época também escrava do mesmo senhor), no engenho Santo Antônio, no termo de Itabaiana, Malaquias foi julgado e condenado à pena de galés perpétuas, mas conseguiu reduzir sua pena para doze anos de prisão com trabalho, após apelar para um novo julgamento meses mais tarde. Isto porque alegou que estava fora de si em virtude de ter consumido aguardente. Segundo os depoimentos das testemunhas, ele praticou o crime motivado por ciúmes, afogando a companheira no Rio das Pedras e, em seguida, nela desferindo diversos golpes de foice por todo o corpo, incluindo alguns no pescoço que quase a deixaram degolada. ${ }^{24}$

Em uma súplica de 29 de agosto de 1894, assinada pelo advogado Samuel Moreno de Alencar Araripe, Malaquias expôs sua visão dos acontecimentos. Retoricamente, culpou o sistema escravista pelo seu suposto estado de falta de "consciência" no momento do crime. Viver em regime de cativeiro, submetido à violência e aos maus tratos, teria desajustado sua personalidade, deixando-o nas trevas, sem educação, sem religião, sem discernimento (entre o bem e o mal) ou senso de responsabilidade. Com a pena de prisão, tudo teria mudado. Não

22 SCHWARCZ, Lilia Moritz. Retrato em branco e negro: jornais, escravos e cidadãos em São Paulo no final do século XX. São Paulo: Companhia das Letras, 1987; XAVIER, Regina Célia Lima. A conquista da liberdade: libertos em Campinas na segunda metade do século XIX. Campinas: Área de Publicaçóes CMU/UNICAMP, 1996; PASSOS SUBRINHO, Josué Modesto dos. Reordenamento do trabalho: trabalho escravo e trabalho livre no Nordeste Açucareiro: Sergipe 1850-1930. Aracaju: FUNCAJU, 2000; FRAGA FILHO, Walter. O cotidiano movediço do pós-abolição: ex-escravizados na cidade de Salvador, 1889-1890. In: DOMINGUES, Petrônio; GOMES, Flávio dos Santos (orgs.). Políticas da raça: experiências e legados da abolição e da pós-emancipação no Brasil. São Paulo: Selo Negro ediçôes, 2014, p. 155-172.

${ }^{23}$ Quando Carlos Costa Ribeiro pesquisou a questão da "cor e criminalidade" na Justiça do Rio de Janeiro no início do século XX, constatou que autores do naipe de Nina Rodrigues, Euclides da Cunha, Nelson Hungria e Arthur Ramos, assim como o pensamento de senso comum na sociedade brasileira na época, acreditavam que negros cometiam mais crimes do que brancos. "Procurei relativizar a ideia do senso comum e dos autores citados mostrando que pretos e pardos sofriam discriminação nos julgamentos judiciais. $\mathrm{O}$ fato de que eram mais condenados não significa que tivessem intrinsecamente qualquer inclinação para o crime. Pode-se dizer, inclusive, que a representação social que relaciona 'cor e raça e criminalidade' contribuía para aumentar as probabilidades de condenação de pretos e pardos e diminuir as chances de condenação de brancos acusados por um mesmo tipo de delito. [...] Ser preto ou pardo não é sinônimo de criminalidade, mas os funcionários jurídico-policiais pareciam não acreditar nisto e tratavam com mais severidade quem não fosse branco". RIBEIRO, Carlos Antonio Costa. Cor e criminalidade: estudo e análise da Justiça no Rio de Janeiro (19001930). Rio de Janeiro: Editora UFRJ, 1995, p. 143-144.

${ }^{24}$ AGJSE. Ref. Arq. AJU/C. TJ. Petição de Graça. Cx. 01/1445. 03/08/1894. 
vivendo mais "semelhante ao animal, vergado do eito do canavial para a cepa do bárbaro tronco de um verdugo", teria encontrado o "nome do bem", "quem o guiasse", tirando-lhe a venda dos olhos. A casa de detençáo teria o regenerado, corrigido seu caráter, seus vícios e sua ignorância. Partindo desse princípio, solicitava ao presidente do Estado a sua liberdade:

Senhor! Nasci escravo, escravo estou, nunca vi a liberdade, o grande e glorioso dia 13 de maio para mim náo existe! Esse raio de luz a mim não alumiou, deixou-me na escuridáo onde me acho.

Senhor, já não sou o ignorante que fui, a prisão, o movimento desta casa já instruíram (sic) me acordaram do letargo em que vivia, imposto pela escuridáo da masmorra da senzala.

De vós tudo espera a suplicante pois que, nele reside o arrependimento e o remorso do crime inconsciente que cometeu; arrependido, cansado, a domado acho-me inteiramente corrigido, portanto Senhor peço-vos perdão e espero a graça. ${ }^{25}$

Continuando sua estratégia retórica, Malaquias alegava agora estar consciente, lúcido, a ponto de se arrepender e sentir remorso pelo crime cometido. Exaltava até o caráter pedagógico e corretivo da cadeia pública de Aracaju. É difícil saber se Malaquias falava a verdade. Carvalho Neto, advogado que conheceu aquela instituição prisional no início do século XX, narra, em livro romanceado de cunho memorialístico, que ali havia preocupação com o "castigo; não se tratava da educação". Pretendia-se a pena "intimidativa, mas não corretiva". Do trabalho - "higiene dos músculos, fonte de saúde, terapia moral" - nada se fazia "com proveito". Longe de se "prestar à execução de qualquer sistema penitenciário racional", ali, sublinhou Carvalho Neto, era um "estranho mundo de vidas perdidas". ${ }^{26}$ Muito provavelmente, Malaquias, em sua súplica, foi estratégico, incorrendo no que James Scott define como "arte do disfarce" e "encenaçáo" dos subordinados quando tentam resistir à dominaçáo. ${ }^{27}$ Em vista de sensibilizar as autoridades públicas para o seu pedido de graça, ele apostou na retórica do escravo pretensamente sociopata, incapaz de "viver por si", que foi regenerado pelo sistema prisional. Seja como for, Malaquias continuava na cadeia pública da capital, privado de sua liberdade, o que, para ele, significava não se desvencilhar da experiência do cativeiro: "Senhor! Nasci escravo, escravo estou". O "glorioso dia 13 de Maio" não teria alterado a sua vida em nada. Estando em uma das selas da cadeia, essa data não implicou para ele o acesso à liberdade. Significou, isso sim, um "raio de luz" que não o alumiou.

Alcançar a concessão da graça não era uma missão fácil. A perversidade com que se deu a morte de Shymphoroza causou a indignação das testemunhas e autoridades enredadas no processo. O Barão de Itabaiana ficou "pasmado" e desistiu do direito de propriedade que

\footnotetext{
${ }^{25}$ Idem.

${ }^{26}$ CARVALHO NETO, Antônio Manoel de. Vidas perdidas. Salvador: Livraria Progresso, 1933, p. 27.

${ }^{27}$ SCOTT, James C. A dominação e a arte da resistência: discursos ocultos. Lisboa: Letra Livre, 2013.
} 
tinha sob o escravo Malaquias. Já as autoridades, amiúde, se referiram ao crime como "bárbaro" e "selvagem". O próprio promotor público não escondeu sua repulsa. $\mathrm{Na}$ "estatística criminal desta comarca", dizia ele, "creio, nenhum assassinato inspira mais indignação que o da mísera Symphoroza, parceira e vítima da crueldade de Malaquias". Por sua vez, o juiz da comarca, João da Silva Mello, produziu um relatório denso sobre o caso, no dia 19 de novembro de 1894, colocando em cheque as palavras de Malaquias, quando já afirmava estar regenerado: quem "poderá afirmar que no fundo do seu coração não se oculta mais perversidade dos seus instintos"? O magistrado continuou questionando: oito "anos de prisão serão suficientes para transformar em alma cândida a natureza perversa de um assassino sem um trabalho metódico, onde a paciência se habilita a formar uma 2a natureza"? Por fim, João Mello entendia que se Malaquias agiu por vontade própria, a pena atual - doze anos com trabalho - deveria ser mais rigorosa. Caso o réu tivesse agido com uma "consciência mal organizada devido à ação delituosa do meio em que vivia" (isto é, sob o efeito dos danos morais do regime escravista, que o impedia de assimilar as noçôes de certo e errado), a condenação era justa e devia ser cumprida até o final. ${ }^{28}$

As reflexões de João da Silva Mello sinalizam para o peso que se atribuía à experiência do cativeiro para a formação da consciência do antigo escravo. Na concepção do magistrado, Malaquias, de tão deformado pela escravidão, era moralmente desregrado e incapaz de viver em uma sociedade livre, em suma, não estava preparado para exercer plenamente seus direitos civis. Seu relatório foi determinante para o desenlace do caso. O procurador geral do Estado acabou indeferindo o pedido de graça no dia 3 de dezembro de 1894 . Com essa decisão, Malaquias frustrou suas expectativas de liberdade e teve que esperar mais algum tempo para ser alumiado pelo "raio de luz".

Curiosamente, uma parcela da historiografia e sociologia brasileiras bebeu em partes dos parâmetros de análises do juiz João da Silva Mello, que via o liberto como desqualificado para se adaptar às condiçóes da sociedade livre em virtude das deficiências herdadas do cativeiro. Autores clássicos nas décadas de 1960 e 1970, como o sociólogo Florestan Fernandes, acreditavam que a "herança da escravidão" provocou nos libertos um estado de alienação, "sociopatia" ou "anomia social", razão pela qual esses sujeitos foram lançados na sociedade livre desprovidos de atributos morais e materiais para nela integrarem-se. ${ }^{29}$ Tanto o discurso de João da Silva Mello (e outras autoridades judiciárias e penitenciárias) quanto as análises acadêmicas das décadas de 1960 e 1970 impuseram ao liberto a pecha de incapaz de se adaptar à "nova ordem". Há, todavia, entre os dois paradigmas explicativos, uma diferença crucial: as elites do final do século XIX não escamoteavam o "medo branco de almas negras", ${ }^{0}$

\footnotetext{
${ }^{28}$ AGJSE. Ref. Arq. AJU/C. TJ. Petição de Graça. Cx. 01/1445. 03/08/1894.

${ }^{29}$ FERNANDES, Florestan. A integração do negro na sociedade de classes. 2 vols. São Paulo: FFLCH/USP, 1964.

${ }^{30}$ CHALHOUB, Sidney. Medo branco de alma negra: escravos, libertos e republicanos na cidade do Rio de Janeiro. Revista Brasileira de História, v. 8, n. 16, 1988, p. 83-105.
} 
e seus argumentos eram instrumentalizados pelo imaginário racista que definia o liberto como um ser inferior e virtualmente patológico ${ }^{31}$, ao passo que a produção acadêmica, ao buscar "apresentar uma explicação histórica sobre aquele momento, acabou por cristalizar como 'verdade' aqueles argumentos que náo poderiam ser analisados fora do contexto em que foram produzidos e das intençóes que carregavam". ${ }^{32}$

É tanto que a historiografia recente tem demonstrado que os libertos e seus descendentes não eram seres bestiais, dotados de uma natureza criminosa, inclinados à vadiagem e tampouco estavam despreparados para a vida em liberdade. Quer no Recôncavo Baiano, quer no Vale do Paraíba, no Oeste Paulista ou mesmo em Sergipe, eles procuravam viver com autonomia, valorizavam os laços familiares (de parentescos e compadrios), forjavam projetos de vida, exerciam ofícios e profissóes (nas cidades e no campo), interagiam e negociavam com outros segmentos da sociedade envolvente, tinham noçôes de direitos, possuíam discernimento político, exigiam ser tratados com dignidade e procuravam, tanto quanto possível, inserir-se socialmente, sem sucumbir aos infortúnios da vida. ${ }^{33}$

Não é de estranhar que os casos, até aqui documentados, indicam libertos, ainda que sentenciados, lendo o mundo à sua volta e, partir daí, urdindo visóes de liberdade, tecendo redes de contatos, solidariedades e informaçóes, traçando estratégias de atuação legal e elaborando narrativas retóricas de reivindicação. Fato é que os libertos sentenciados se mostravam capazes de se articular para capitalizar os novos direitos que a legislação lhes conferia. Evidentemente, a lei estadual no 12, de 27 de julho de 1892, que regia o perdão e a comutação de pena, não foi pensada para proporcionar ao ex-escravos a busca individual pela liberdade. Entretanto, esses sujeitos souberam testar, afinal, as vias institucionais abertas pela nova conjuntura legal e política. A ânsia da liberdade entrelaçava-se às expectativas de fruição de direitos e cidadania. Alquimia difícil, porosa, incerta, mas que lembrava a indeterminação histórica na qual se encerrava a vida daqueles libertos.

Afora Odorico, Rufino e Malaquias, outra trajetória que encontramos nas fontes coligidas nas caixas do AGJES foi a de João, menor de 21 anos, também identificado como "ex-escravo", que integrou o plantel do tenente-coronel Manoel da Fonseca Menezes. Ele foi condenado a galés perpétuas por ter assassinado "barbaramente" o malfadado Raphael den-

\footnotetext{
${ }^{31}$ SCHWARCZ, Lilia Moritz. O espetáculo das raças: cientistas, instituiçôes e questáo racial no Brasil. São Paulo: Companhia das Letras, 1993; BORGES, Dain. "Puffy, ugly, slothful, and inert': degeneration in Brazilian social thought, 1880-1940". Journal of Latin American Studies, v. 25, n. 2, 1993, p. 235-256.

${ }^{32}$ MENDONÇA, Joseli Maria Nunes. Entre a mão e os anéis: a Lei dos Sexagenários e os caminhos da abolição no Brasil. Campinas: Editora da UNICAMP, 1999, p. 58.

${ }^{33}$ MATTOS, Hebe; RIOS, Ana Lugão. Memórias do cativeiro: família, trabalho e cidadania no pós-abolição. Rio de Janeiro: Civilização Brasileira, 2005; FRAGA FILHO, Walter. Encruzilhadas da liberdade: histórias de escravos e libertos na Bahia (1870-1910). Campinas, SP: Editora da Unicamp, 2006; MONSMA, Karl. A reprodução do racismo: fazendeiros, negros e imigrantes no Oeste paulista, 1880-1914. São Carlos: EdUSFCAR, 2016; SOUZA NETO, Edvaldo Alves de. Saindo das senzalas, mas não da história: libertos em Sergipe no pós-abolição (1888-1900). São Cristóvão: Editora UFS, 2017.
} 
tro da casa de roça do tenente-coronel, situada nas matas de Pedra Mole, no termo de Itabaiana, em 26 de março de 1881. Novamente, apareceu a denúncia de que um "ex-escravo" foi vítima dos abusos cometidos por um tribunal formado por parentes e amigos íntimos do seu antigo senhor. ${ }^{34}$

Nos dois interrogatórios, João afirmou ser natural do Engenho Limoeiro, na freguesia de Campo do Brito, no termo de Itabaiana. Era "trabalhador da enxada" e morava em Pedra Molle, "nas roças do seu senhor". Quando questionado sobre o crime que o levou à condenação, disse que assassinou Raphael a convite de "seu parceiro" Maurício, também escravo da propriedade. Tudo aconteceu depois que ele saiu da roça de algodáo e reuniu alguns cavalos para dar água e banho, tarefa que realizava costumeiramente. Nesse ínterim, encontrou Maurício, enforcando Raphael em uma rede estendida próximo à sua casa. Percebendo sua presença, Maurício o chamou para "acabar de matar" Raphael, que ainda agonizava. Então, ambos colocaram o corpo da vítima na rede e o arrastaram até uma mata de juazeiro adjacente à propriedade, onde Raphael, ainda com vida, permaneceu em surdina. Executado o plano, saíram um pouco mais cedo da roça para que os outros escravos não desconfiassem de nada e, novamente, arrastaram o corpo de Raphael da mata até uma gruta, onde finalmente deram cabo da vida do seu antigo companheiro de eito. Por ser um local de difícil acesso, o corpo só foi encontrado dias depois pelos “corvos ou urubus", já em estado de putrefação. João justificou que cometeu o crime porque Raphael "fazia arengas quando seu senhor ali chegava”.

No relatório do juiz do termo de Itabaiana, João da Silva Mello (o mesmo do caso anterior), redigido no ano de 1893 e anexado à petição de graça impetrada por João, é possível verificar a perplexidade do magistrado frente à crueldade com que foi cometido o crime e o aparente sangue frio demonstrado pelo réu durante sua execução. Mais do que isso, o magistrado fornecia elementos de sua percepção sobre os últimos anos do regime escravista:

Nem se pode admitir que os rigores do cativeiro houvessem determinado ao réu a confissão de um crime, que depois diz não ter cometido.

Não é justificável perante a razão que o réu pretendesse livrar-se dos rigores do cativeiro para sujeitar-se a uma escravidão mais rigorosa ao cumprimento da pena, principalmente em uma época, que para o cativeiro - bem se podia chamar de transição.

As leis a respeito continham não só uma promessa de liberdade ao escravo, como também uma realidade, em algumas de suas benéficas disposiçóes.

A esperança, ainda mesmo nas horas de mais negra desilusão da vida penosa do escravo, era a força moral, que resignava-lhe a alma, e despertava-lhe o instinto de sua futura liberdade, no meio das incertezas e dos podres, em que flutuava a sua existência. ${ }^{35}$

\footnotetext{
${ }^{34}$ AGJES. AJU/C. TJ. Escravos. Cx. 01/1463 - 26/05/1893.

${ }^{35} \mathrm{Idem}$.
} 
No entender do magistrado, as condiçóes de vida adversas do "ex-escravo" João no período de vigência do cativeiro não justificavam sua atitude. Isso porque o regime escravista já estava em processo de "transição". Julgava contraditório que o réu pretendia alcançar a liberdade optando em se tornar alvo das penas mais severas previstas no código criminal, em vez de aproveitar as "benéficas disposições" da legislação abolicionista que poderiam garantir a liberdade frente aos horrores do cativeiro. Ou seja, seria mais fácil para João, como escravo, alcançar a liberdade pelas vias legais de um sistema escravista, cada vez mais minado em sua legitimidade, do que incidindo em crime comum, ao assassinar o seu companheiro de infortúnio por ter denunciado suas faltas ao seu senhor.

O relatório do juiz do termo de Itabaiana parece ter sido fundamental para o indeferimento do pedido de graça. O liberto João perdera a ação judicial, malgrado seu advogado ter anexado ao processo a comprovação do seu bom comportamento na casa de prisão de Aracaju. Para Silveira Brito, o procurador geral do estado de Sergipe, nomeado para representar o presidente do Estado, a "perversidade" com que foi cometido o delito tornava o "impetrante indigno da graça" que pleiteava. Abortava, ao menos provisoriamente, as aspiraçôes de liberdade que João alimentava; aos olhos da justiça, ele era outro "ex-escravo" que ainda não estava em condiçôes de ser incorporado à sociedade como cidadão.

Ao longo do tempo, a justiça se transformou em trincheira de debates, contendas e disputas de projetos de liberdade e cidadania. Os políticos podiam criar leis, mas, quando surgiam as divergências e conflitos, eram os procuradores, juízes e os júris que as aplicavam. A forma de utilização das leis ajuda-nos a entender como as açôes eram resolvidas, e como eram fundamentados alguns de seus argumentos. As expressóes dos juristas e operadores de direito, as palavras que eles utilizavam, as percepçóes políticas, as figuras de retóricas podiam ser importantes para a compreensão do sentido atribuído à lei. ${ }^{36}$ É nesse contexto que emergiam as diferentes interpretaçóes em torno das açóes, bem como os diversos encaminhamentos jurídicos relativos à questão da liberdade. Em uma sociedade recém-saída da escravidão, quando nem sempre existiam normas de direito previstas para todos os tipos de ocorrência, os resultados das açóes eram imprevisíveis.

\section{Outras estratégias}

Vislumbrar a liberdade manejando os canais da justiça não era novidade alguma para os sujeitos que haviam passado pela experiência do cativeiro. Essa era uma arena que já vinha sendo demandada pelos escravos sergipanos e de outras partes das Américas ${ }^{37}$, no cenário

\footnotetext{
${ }^{36}$ GRINBERG, Keila. Liberata: a lei da ambiguidade - as açóes de liberdade da Corte de Apelação do Rio de Janeiro, século XIX. Rio de Janeiro: Relume-Dumará, 1994, p. 92.

${ }^{37}$ CHALHOUB, Sidney. Visóes da liberdade: uma história das últimas décadas da escravidão na corte. São Paulo: Companhia das Letras, 1990; MENDONÇA, Joseli Maria Nunes. Entre a mão e os anéis: a Lei dos
} 
brasileiro, isso se deu sobretudo a partir da aprovação da Lei do Ventre Livre de 1871, que redimensionou as relaçôes entre senhores e escravos. Como o próprio nome sugere, seu ponto principal era a concessão de liberdade aos filhos de todas as escravas que nascessem a partir do momento em que a lei entrasse em vigor. Ao mesmo tempo, ela estabelecia um ponto-chave: reconhecia ao escravo o direito de formação de pecúlio, por meio do qual poderia fazer o que bem entendesse, inclusive comprar sua liberdade, com ou sem o consentimento do senhor. De acordo com Sharyse Amaral, os escravos em Sergipe souberam utilizar de forma perspicaz desse dispositivo legal durante a vigência da escravidão. ${ }^{38}$ Por que não o fariam para continuar defendendo seus direitos, uma vez o regime de trabalho escravo abolido?

Os libertos percebiam de diferentes maneiras seus direitos, ainda que enfeixados pelas formas como a escravidão e a liberdade eram legalmente configuradas em cada contexto. No que concerne aos libertos sentenciados, além de instrumentalizarem a lei estadual $n^{\circ} 12$, que regulamentava os pedidos de comutação ou perdão da pena, eles também souberam aproveitar das alterações legais proporcionadas pelo Decreto Federal no 847, sancionado em 11 de outubro de 1890, que instituiu o novo código criminal, cerca de um ano após a implantação da República. ${ }^{39}$ Por meio dessa nova legislação nacional, os libertos sentenciados também passaram a provocar a justiça e requerer a revisão de suas penas.

Foi atento a essa possibilidade aberta pela nova conjuntura legal e política que Pedro, liberto, recolhido na casa de prisão da capital desde 1886 e contando com o auxílio de um advogado, recorreu às barras dos tribunais para solicitar uma revisão da sua pena consoante os ditames do novo código criminal. Condenado pelo júri de Laranjeiras, interior de Sergipe, à pena máxima prevista no artigo 205 da legislação imperial - nove anos e quatro meses de prisão pelo crime de ferimento -, ele solicitava, em 1891, que a sua pena fosse reduzida. Afirmava que seu pedido estava "escudado pela benéfica disposição do artigo 3o, letra (b),

Sexagenários e os caminhos da abolição no Brasil. Campinas: Editora da UNICAMP, 1999; PENA, Eduardo Spiller. Pajens da casa imperial: jurisconsultos, escravidão e a lei de 1871. Campinas: Editora da UNICAMP, 2001; AZEVEDO, Elciene. O direito dos escravos: lutas jurídicas e abolicionismo na província de São Paulo. Campinas: Ed. Unicamp, 2010; GRINBERG, Keila; PEABODY, Sue. Escravidão e liberdade nas Américas. Rio de Janeiro: Ed. FGV, 2013; SANTOS, Moisés Augustinho dos Santos. "O sagrado direito de liberdade": experiências de escravos nos tribunais da Comarca de Estância/Sergipe (1871-1888). Dissertação (Mestrado em História) - CECH, UFS. São Cristóvão, 2017.

${ }^{38}$ AMARAL, Sharyse Piroupo do. Um pé calçado outro no chão: liberdade e escravidão em Sergipe. Salvador: EDUFBA; Aracaju: Editora Diário Oficial, 2012, p. 201-259.

39 Conforme ressalta Amy Chazkel, "O regime republicano logo percebeu a necessidade de promulgar uma nova legislação em substituição ao Código Criminal de 1830, que estava manchado com os vestígios ainda da escravidáo e da cruel pena de açoites, com a pena infamante das galés, com a morte cominada até aos crimes políticos, a perpetuidade dos castigos em grande número de casos, e a imprescritibilidade em todos. $\mathrm{O}$ Código Penal de 1890 e a nova legislação republicana aboliram as galés, o banimento, o desterro e o degredo; transformaram a prisão perpétua em termos de trintas anos e implementaram outras reformas para tornar o encarceramento mais sistemático e humano". CHAZKEL, Amy. Uma perigosíssima lição: a casa de detenção do Rio de Janeiro na Primeira República. In: MAIA, Clarissa Nunes et al (orgs.). História das prisóes no Brasil. v. 2. Rio de Janeiro: Rocco, 2009, p. 12. 
do novo código criminal" republicano, segundo o qual devia ser aplicada a nova legislação quando o réu fosse enquadrado em uma pena menos rigorosa. Para o crime de ferimento, como o cometido por Pedro, o recém-aprovado código criminal previa, em seu artigo 304, a pena de quatro anos de prisão celular. Independentemente da linguagem truncada e dos caminhos pantanosos existentes nos domínios da lei ou de suas brechas, interessa-nos saber que a estratégia adotada por Pedro, caso aceita, seria o seu passaporte para a liberdade, uma vez que já tinha cumprido mais de cinco anos de prisão. ${ }^{40}$

Infelizmente, a petição encontra-se incompleta e em estágio de decomposição um tanto avançado; não há como saber ao certo se Pedro adquiriu a alcunha de liberto antes ou depois do 13 de maio de 1888, embora tenha recebido a "boa-nova" da Abolição em uma das celas da casa de prisão da capital. $\mathrm{O}$ juiz, que produziu o relatório anexado às peças do processo, determinou que Pedro fosse "posto imediatamente em liberdade", o que tudo indica deve ter acontecido.

Os libertos confinados na cadeia pública de Aracaju buscaram, de diferentes formas, explorar os mecanismos legais disponíveis em vista de conquistar a liberdade. Outro que se utilizou, astutamente, desses mecanismos foi Bemvindo. Residente no engenho Manguinhos de propriedade de José Apolinário do Prado, de quem também era escravo, Bemvindo tinha 30 anos de idade, era solteiro e trabalhava na lavoura quando foi preso por ter arquitetado e praticado o furto de diversos objetos - roupas, armas, mantimentos, etc. - do estabelecimento comercial do português Antônio Jorge D’Andrade, na noite de 17 para 18 de fevereiro de 1885. Por conta desse crime, pegou uma pena de oito anos de prisão mais vinte por cento do valor roubado. ${ }^{41}$

Em 3 de junho de 1891, Bemvindo, por intermédio de um advogado, entrou na justiça com um pedido de revisão da pena, com base na nova legislaçáo republicana. Qual seja, a pouco menos de um ano da aprovaçáo do novo código criminal, o seu advogado, que o identificava a partir da alcunha de liberto, já acionava as autoridades em favor de um "incauto cidadão, benéfico de justiça”. ${ }^{42}$

Não foi possível saber qual a resposta dada pelas autoridades a essa petição; nos autos do processo não localizamos informaçóes a respeito. Contudo, é muito plausível que o pedido de Bemvindo não tenha prosperado, pois dois anos depois, em 1893, ele encaminhou um pedido de graça ao Tribunal da Relação, assumindo, à luz do decreto estadual $n^{\circ} 12$, de 1892, uma nova estratégia para alcançar a tão aguardada liberdade. Se, na primeira tentativa, ele foi referenciado sob o epíteto de liberto, na petiçáo de graça, Bemvindo, assim como nos demais casos apresentados, não conseguiu fugir do estigma do "ex-escravo", bastante presente, aliás, no vocabulário da burocracia judiciária.

\footnotetext{
${ }^{40}$ Cf. AGJSE. LAR/C. $1^{\circ}$ OF - Restos de Processo - Cx. 01/306.

${ }^{41}$ AGJSE. Ref. Arq. AJU/1a V. CRI. Processo Crime Roubo. Cx. 02/2612. 18/12/1885.

${ }^{42}$ AGJSE. Ref. Arq. AJU/C. TJ. Escravos. Cx. 01/1463. 26/01/1893.
} 
O seu advogado buscou evidenciar os vícios cometidos pelas autoridades na condução do processo, como, por exemplo: enquanto a lei estabelecia o mínimo de cinco testemunhas, foram ouvidas uma informante e quatro testemunhas, sendo que nenhuma delas presenciou o roubo. "Como se condena em tais condiçôes?", o advogado indagava ao presidente do Estado, se "nem se quer foi encontrado objeto algum do roubo em poder do impetrante". Novamente, a justiça estaria agindo por interesses distintos daqueles previstos na legislação, com o intuito de manter encarcerados sujeitos considerados indesejáveis ao convívio social, o que, na concepçáo do advogado, não era novidade, pois

assim é 'Exm. Snr.' as cadeias estão repletas de presos, e a maior parte nestas condiçóes [degradantes]. Não se procede com a verdadeira justiça, quando perante os tribunais comparece um infeliz; todas as vistas emergem-se contra ele, e não admitem razóes. ${ }^{43}$

Em seu relatório, João de Araújo Lima, juiz de Aracaju, reconheceu alguns dos problemas apontados pelo advogado de Bemvindo, visto que, de acordo com as provas testemunhais, havia apenas indícios de que o impetrante era um dos autores do crime. Admitiu também que nada conhecia sobre a vida pregressa de Bemvindo, que, por sinal, não teve sua conduta na cadeia examinada, já que não foi anexado aos autos qualquer tipo de solicitação ao administrador daquela instituição. Certo é que, condenado num processo emaranhado de vários vícios, o impetrante estava detido há mais de sete anos. Faltando apenas quatro meses para concluir a pena, em 7 de fevereiro de 1893, o procurador geral do estado de Sergipe deferiu o pedido de graça de Bemvindo. No dia 24 do mesmo mês, data em que se comemorava o aniversário da promulgação da primeira Constituição republicana, ele teve a liberdade oficializada mediante um decreto assinado por José de Calazans, o presidente do estado de Sergipe. Tal medida governamental representou um desfecho vitorioso para essa e outras histórias de lutas, pois consta que, afora Bemvindo, os "ex-escravos" José Antônio Teixeira e Manoel Martins dos Santos também conseguiram o indulto da pena. ${ }^{44}$ Caminhos trilhados em locais e momentos distintos, mas que revelam experiências comuns de libertos que, embora encarcerados em condições aviltantes, souberam capitalizar o aparato jurídico em uma empreitada labiríntica em prol da liberdade, anos depois da extinção do cativeiro.

\section{Considerações finais}

Qual a diferença entre escravidáo e liberdade? "Para as pessoas que viveram no mundo atlântico entre os séculos XVI e XIX”, ponderam Keila Grinberg e Sue Peabody, "a diferen-

\footnotetext{
${ }^{43}$ Idem.

${ }^{44}$ CARDOSO, Brício; ROMÉRO, Benilde. Compilação das leis, decretos e regulamentos do Estado de Sergipe. v. II, 1892-1893. Aracaju: Tipografia d'O Estado de Sergipe, 1900, p. 679.
} 
ciação entre escravidão e liberdade era algo central para suas experiências", ainda que esses termos fossem fluidos e encerrassem "muitas gradaçôes e implicaçôes sociais". ${ }^{45}$ Quais os parâmetros que definiam a liberdade? Na medida em que o artigo se dedicou às formas de sua obtenção, podemos notar o quanto a condição dos libertos instituía ambiguidades, percepçôes e experiências variadas. Para além da liberdade "legal", almejava-se a liberdade "efetiva". A abordagem aqui pretendeu ser mais microscópica, o que acabou centrando-se, em virtude da própria natureza das fontes, em alguns indivíduos. Essa limitação fez com que, em nenhum momento, procurássemos propor explicaçóes generalizantes ou totalizantes. De todo modo, cremos que podemos chegar a algumas constataçóes importantes. A palavra liberto, que parecia ter uma definição genérica e homogênea quando vista à distância, multifacetou-se quando restringimos o foco de nossa análise. ${ }^{46}$

Este artigo focalizou a atitude dos "ex-escravos" presidiários que enfrentaram as trincheiras da justiça sergipana para fazer valer direitos que consideravam possuir, entre os quais o de receber a liberdade franqueada pela Abolição. Os libertos não estavam, porém, sozinhos em sua aproximaçáo com o mundo do direito. Sua busca por liberdade era encampada por bacharéis e rábulas que, nas salas e corredores dos tribunais, assumiam a sua defesa, elaborando estratégias e argumentaçóes jurídicas que sustentassem tecnicamente sua causa. Os tribunais cumpriram um papel importante para a obtenção da liberdade. Essa importância é evidenciada não apenas pelos pedidos de perdão ou comutação da pena per si, mas, principalmente, pelas sentenças favoráveis à efetiva liberdade dos peticionários.

Aqui, o universo jurídico, abordado muitas vezes como um espaço de manobra maquiavélica do Estado e dos setores dominantes, apareceu como uma trincheira onde se deflagrava o embate de diferentes atores com concepçôes e intençôes não apenas distintas, como conflitantes. É verdade que os libertos sentenciados, por vezes, saíram derrotados nos processos de pedidos de graça, porém, noutras, conseguiram provar seus direitos nos tribunais, obtendo o induto ou a comutaçáo da pena.

Ao examinar as expectativas de liberdade dessas pessoas e suas refregas na justiça, é possível perceber que a liberdade não era algo desprovido de importância, nem era sentida como uma mera ilusão. Tinha significados bem específicos para elas, que desejavam e esperavam há tempos para sair de trás das grades. Do ponto de vista delas, permanecer "condenado dentro de uma penitenciária" significava não romper, simbolicamente, com as correntes e grilhôes de um "bárbaro cativeiro". Importava, assim, a conquista de direitos antes inexistentes e a ampliação daqueles já consagrados, de alteração das relaçôes sociais hierárquicas baseadas no mando e na obediência, das possibilidades de exercício da cidadania plena.

\footnotetext{
${ }^{45}$ GRINBERG, Keila; PEABODY, Sue. Escravidão e liberdade nas Américas. Rio de Janeiro: Ed. FGV, 2013, p. 7-8.

${ }^{46}$ XAVIER, Regina Célia Lima. A conquista da liberdade: libertos em Campinas na segunda metade do século XIX. Campinas: Área de Publicaçóes CMU/UNICAMP, 1996.
} 
Movidos por esses significados, lutaram com as armas que julgavam mais eficientes, tensionando a nova ordem legal, institucional e política com suas reivindicaçóes.

Talvez essa atitude dos libertos sentenciados possa ser designada de "infrapolítica", para adotarmos uma categoria analítica de James Scott. Infrapolítica porque assumia um caráter, como os raios infravermelhos, para lá da parte visível. Aquela atitude consistia no cimento da ação política na esfera pública, através da qual "os de baixo" iam pondo constantemente à prova os limites da dominação e desafiando as suas fronteiras, travando, desse modo, uma luta de posiçóes próxima da guerra de guerrilha. Scott sublinha o potencial que a infrapolítica implica como mecanismo para desencadear novos tipos de desafios e alterar as relaçôes de poder. ${ }^{47}$

Com as mudanças jurídicas e políticas desencadeadas pela abolição da escravidão, as possibilidades de acesso à justiça se alteraram. O que resta saber é de que forma e com qual dimensão tais alteraçôes contribuíram para os libertos redefinirem suas lutas e projetos. Enfronhados em uma sociedade onde a conquista da cidadania republicana náo significou o fim das desigualdades sociais, aqueles sujeitos continuaram sua batalha por direitos. Pelo menos na justiça, eram ouvidos e tentavam exumar o fantasma do que eles entendiam por viver em regime análogo ao da escravidão. Longe de vítimas indefesas, os libertos se revelaram sujeitos proativos na conformação de espaços públicos de negociaçóes sociais, capazes de se apropriar da própria lógica de seus adversários. Tirados da invisibilidade em que até agora se encontravam, eles trazem outras perspectivas para a análise dos significados da abolição em Sergipe, para não dizer no Brasil.

\section{Fontes}

ARQUIVO GERAL DO JUDICIÁRIO DO ESTADO DE SERGIPE (AGJES): AJU/C. TJ. Queixa Crime. Cx. 01/1461 - 05/07/1895; AJU/C. TJ. Penal. Petição de graça. Cx. 01/1445 - 01/07/1895; AJU/C. TJ. Escravos. Cx.01/1463 - 24/12/1895; AJU/C. TJ. Petição de Graça. Cx. 01/1445. 03/08/1894; AJU/C. TJ. Escravos. Cx. 01/1463 26/05/1893; LAR/C. $1^{\circ}$ OF - Restos de Processo - Cx. 01/306; AJU/1a V. CRI. Processo Crime Roubo. Cx. 02/2612. 18/12/1885; AJU/C. TJ. Escravos. Cx. 01/1463. 26/01/1893. GAZETA DE SERGIPE. Embarque. Aracaju, 22 mar. 1890, p. 2.

\footnotetext{
${ }^{47}$ SCOTT, James C. A dominação e a arte da resistência: discursos ocultos. Lisboa: Letra Livre, 2013, p. 253275.
} 


\section{Referências}

AMARAL, SharysePiroupo do. Um pé calçado outro no chão: liberdade e escravidão em Sergipe. Salvador: EDUFBA; Aracaju: Editora Diário Oficial, 2012.

AZEVEDO, Célia Maria Marinho de. Onda negra, medo branco: o negro no imaginário das elites - século XIX. $3^{a}$ ed. São Paulo: Annablume, 2004.

AZEVEDO, Elciene. $O$ direito dos escravos: lutas jurídicas e abolicionismo na província de São Paulo. Campinas: Ed. Unicamp, 2010.

BORGES, Dain. "'Puffy, ugly, slothful, and inert': degeneration in Brazilian social thought, 1880-1940". Journal of Latin American Studies, v. 25, n. 2, 1993, p. 235-256.

BRETAS, Marcos Luiz. O que os olhos não veem: histórias das prisóes no Rio de Janeiro. In: MAIA, Clarissa Nunes et al (orgs.). História das prisóes no Brasil. v. 2. Rio de Janeiro: Rocco, 2009, p. 185-213.

CARDOSO, Amâncio. O quinto dos infernos: presídios em Sergipe no século XIX. In: MENEZES, Joelina (org.). Segurança pública: gestão, formação e valores. São Cristóvão: Editora UFS, 2012, p. 185-194.

CARDOSO, Brício; ROMÉRO, Benilde. Compilaçâa das leis, decretos e regulamentos do Estado de Sergipe. II volume, 1892-1893. Aracaju: Tipografia d'O Estado de Sergipe, 1900.

CARVALHO NETO, Antônio Manoel de. Vidas perdidas. Salvador: Livraria Progresso, 1933.

CHALHOUB, Sidney. Medo branco de alma negra: escravos, libertos e republicanos na cidade do Rio de Janeiro. Revista Brasileira de História, v. 8, n. 16, 1988, p. 83-105.

CHALHOUB, Sidney. Visóes da liberdade: uma história das últimas décadas da escravidão na corte. São Paulo: Companhia das Letras, 1990.

CHAZKEL, Amy. Uma perigosíssima lição: a casa de detenção do Rio de Janeiro na Primeira República. In: MAIA, Clarissa Nunes et al (orgs.). História das prisóes no Brasil. v. 2. Rio de Janeiro: Rocco, 2009, p. 7-45.

CUNHA, Maria Gomes da; GOMES, Flavio dos Santos (orgs.). Quase-cidadão: histórias e antropologias do pós-emancipação no Brasil. Rio de Janeiro: Editora FGV, 2007.

DOMINGUES, Petrônio; ALVES, Edvaldo e NUNES, Cláudia. O "cativeiro se acabou": experiências de libertos em Sergipe no pós-abolição. História, Histórias. Brasília, v. 4, n. 8, 2016, p. 93-112.

FERNANDES, Florestan. A integração do negro na sociedade de classes. 2 vols. São Paulo: FFLCH/USP, 1964.

FRAGA FILHO, Walter. O cotidiano movediço do pós-abolição: ex-escravizados na cidade de Salvador, 1889-1890. In: DOMINGUES, Petrônio; GOMES, Flávio dos Santos (orgs.). 
Políticas da raça: experiências e legados da abolição e da pós-emancipação no Brasil. São Paulo: Selo Negro ediçóes, 2014, p. 155-172.

FRAGA FILHO, Walter. Encruzilhadas da liberdade: histórias de escravos e libertos na Bahia (1870-1910). Campinas, SP: Editora da Unicamp, 2006.

GRINBERG, Keila. Liberata: a lei da ambiguidade - as açóes de liberdade da Corte de Apelação do Rio de Janeiro, século XIX. Rio de Janeiro: Relume-Dumará, 1994.

GRINBERG, Keila; PEABODY, Sue. Escravidão e liberdade nas Américas. Rio de Janeiro: Ed. FGV, 2013.

LISBOA, Silva L. C. Chorografia do Estado de Sergipe. Aracaju: Imprensa Oficial, 1897.

MATTOS, Hebe; RIOS, Ana Maria. O pós-abolição como problema histórico: balanço e perspectivas. Topoi, v. 5, n. 8, 2004, p. 170-198.

MATTOS, Hebe; RIOS, Ana Lugão. Memórias do cativeiro: família, trabalho e cidadania no pós-abolição. Rio de Janeiro: Civilização Brasileira, 2005.

MENDONÇA, Joseli Maria Nunes. Entre a mão e os anéis: a Lei dos Sexagenários e os caminhos da abolição no Brasil. Campinas: Editora da UNICAMP, 1999.

MONSMA, Karl. A reprodução do racismo: fazendeiros, negros e imigrantes no Oeste paulista, 1880-1914. São Carlos: EdUSFCAR, 2016.

PASSOS SUBRINHO, Josué Modesto dos. Reordenamento do trabalho: trabalho escravo e trabalho livre no Nordeste Açucareiro: Sergipe 1850-1930. Aracaju: FUNCAJU, 2000.

PENA, Eduardo Spiller. Pajens da casa imperial: jurisconsultos, escravidáo e a lei de 1871. Campinas: Editora da UNICAMP, 2001.

RIBEIRO, Carlos Antonio Costa. Cor e criminalidade: estudo e análise da Justiça no Rio de Janeiro (1900-1930). Rio de Janeiro: Editora UFRJ, 1995.

SANTOS, Moisés Augustinho dos Santos. "O sagrado direito de liberdade": experiências de escravos nos tribunais da Comarca de Estância/Sergipe (1871-1888). Dissertação (Mestrado em História) - CECH, UFS. São Cristóvão, 2017.

SCHWARCZ, Lilia Moritz. Retrato em branco e negro: jornais, escravos e cidadãos em São Paulo no final do século XX. São Paulo: Companhia das Letras, 1987.

SCHWARCZ, Lilia Moritz. O espetáculo das raças: cientistas, instituiçóes e questáo racial no Brasil. São Paulo: Companhia das Letras, 1993.

SCOTT, James C. A dominação e a arte da resistência: discursos ocultos. Lisboa: Letra Livre, 2013.

SEBRÃO SOBRINHO. Laudas da história de Aracaju. Aracaju: Regina, 1955.

SOUZA NETO, Edvaldo Alves de. Saindo das senzalas, mas não da história: libertos em Sergipe no pós-abolição (1888-1900). São Cristóvão: Editora UFS, 2017. 


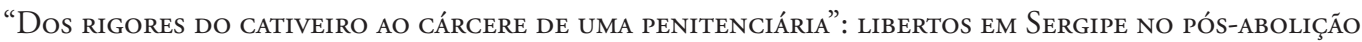

Petrônio Domingues e Edvaldo Alves de Souza

THOMPSON, E. P. Senhores e caçadores: a origem da lei negra. Rio de Janeiro: Paz e Terra, 1987.

XAVIER, Regina Célia Lima. A conquista da liberdade: libertos em Campinas na segunda metade do século XIX. Campinas: Área de Publicaçôes CMU/UNICAMP, 1996. 